\title{
METODE WEIGHTED MOVING AVERAGE DALAM M-FORECASTING
}

\author{
Akmal Nasution \\ Program Studi Sistem Informasi, STMIK Royal Kisaran \\ email:nst.akmal@gmail.com
}

\begin{abstract}
M-Forecasting or Mobile Forecasting can be interpreted as mobile-based forecasting. Forecasting here means predicting a situation in the future. The use of mobile technology in forecasting is considered appropriate to improve the efficiency of forecasting to be carried out, this is supported by the development of increasingly mobile technology, where digital marketing marketing research institutions estimate that in 2018 the number of active smartphone users in Indonesia is more than 100 million people. This fantastic amount can be utilized by the development of mobile-based information systems for forecasting. Predictions of a forecast can be realized by using several methods. The Weighted Moving Average method is one of them. This method provides predictions for the future by utilizing previous data and giving different weights for each data used. The level of confidence in forecasting can be determined by measuring the error percentage of the forecasting obtained. The higher the error rate can be interpreted that the forecasting results obtained are increasingly unreliable or inaccurate, and vice versa. This forecasting technique can be applied in various fields of work, including in forecasting rubber production. By obtaining forecasting data on rubber production in the future, of course, it can provide an overview of future work steps, so that it can increase the company's work productivity. Based on this, the researchers intend to build a mobile-based forecasting application system, so that it can be installed in a mobile device later, especially mobile technology with the Android operating system.
\end{abstract}

Keywords: Forecasting, Mobile, Android, Weighted Moving Average.

Abstrak: M-Forecasting atau Mobile Forecasting dapat diartikan sebagai peramalan berbasis mobile. Peramalan disini berarti memprediksi suatu keadaan dimasa mendatang. Penggunaan teknologi mobile dalam peramalan dianggap tepat untuk meningkatkan efisiensi peramalan yang akan dilakukan, hal ini didukung dengan perkembangan teknologi mobile yang kian pesat, dimana lembaga riset digital marketing emarketer memperkirakan pada 2018 jumlah pengguna aktif smartphone di Indonesia lebih dari 100 juta orang. Jumlah yang fantastis ini dapat dimanfaatkan dengan pengembangan sistem informasi berbasis mobile untuk peramalan. Prediksi dari sebuah peramalan dapat terwujud dengan penggunaan beberapa metode. Metode Weighted Moving Average adalah salah satunya. Metode ini memberikan prediksi masa depan dengan memanfaatkan data-data terdahulu dan memberikan bobot yang berbeda-beda untuk setiap data yang digunakan. Tingkat kepercayaan peramalan dapat diketahui dengan mengukur persentase eror dari peramalan yang diperoleh. Semakin tinggi tingkat eror dapat diartikan bahwa hasil peramalan yang diperoleh semakin tidak dapat dipercaya atau tidak akurat, begitu juga sebaliknya. Teknik peramalan ini dapat diterapkan diberbagai bidang pekerjaan, termasuk dalam peramalan produksi karet. Dengan memperoleh data peramalan produksi karet dimasa mendatang tentunya dapat memberikan gambaran untuk langkah-langkah kerja kedepannya, sehingga dapat meningkatkan produktivitas kerja perusahaan. Berdasarkan hal tersebut, peneliti bermaksud membangun sebuah sistem aplikasi peramalan berbasis mobile, sehingga dapat dipasang diperangkat mobile nantinya, khususnya teknologi mobile dengan sistem operasi android.

Kata Kunci: Forecasting, Mobile, Android, Weighted Moving Average. 
DOI: https://doi.org/10.33330/jurteksi.v5i2.355

Available online at http://jurnal.stmikroyal.ac.id/index.php/jurteksi

\section{PENDAHULUAN}

Teknologi mobile sekarang ini berkembang pesat, seperti terlihat dari lembaga riset digital marketing, emarketer yang memperkirakan pada 2018 jumlah pengguna aktif smartphone di Indonesia lebih dari 100 juta orang, selain itu data yang dihimpun tentang perangkat mobile yang saat ini penggunanya di Indonesia mencapai 177,9 juta pengguna dengan tingkat penetrasi mencapai $67 \%$ [1]. Teknologi mobile dengan dampak perkembangan terbesar adalah sistem operasi Android. Sistem operasi mobile ini menjadi primadona dikalangan pengguna smartphone sekarang ini.

Bila ditinjau dari segi bahasa kata mobile adalah kata sifat yang berarti dapat bergerak atau dapat digerakkan dengan bebas dan mudah. Namun mobile dapat pula diartikan sebuah benda yang berteknologi tinggi dan dapat bergerak tanpa menggunakan kabel. Contohnya seperti smartphone dan tablet. Mobile juga bisa diartikan kendaraan bermotor yang dapat bergerak. Mobile bersifat bebas seperti air dan dapat mengalir kemanapun. Mobile dapat berubah dan diubah dengan mudah [2]. Pengertian mobile dalam penelitian ini berarti sebuah program yang dapat menjangkau seluruh tempat bisa diakses dengan mudah dan dapat diganti kapan saja tanpa kesulitan.

Sementara forecasting dalam penelitian ini memiliki beberapa definisi berdasarkan pendapat para ahli. "Forecasting atau peramalan adalah pernyataan mengenai nilai yang akan datang dari variabel. Prediksi yang lebih baik dapat menjadi keputusan dengan menggunakan banyak informasi" [3]. "Peramalan (forecasting) adalah suatu seni dan ilmu pengetahuan dalam memprediksi peristiwa pada masa yang akan datang. Peramalan akan melibatkan mengambil data historis (seperti penjualan tahun lalu) dan memproyeksikan mereka ke masa yang akan datang dengan menggunakan model matematika" [4]. Jadi dapat disimpulkan bahwa forecasting (peramalan) adalah seni dan ilmu memprediksi peristiwaperistiwa yang akan terjadi, dengan menggunakan data historis dan memproyeksikannya ke masa depan dengan beberapa bentuk model matematis

Berdasarkan pengertian-pengertian yang dibahas sebelumnya maksud $m$ forecasting atau Mobile Forecasting dalam penelitian ini adalah peramalan berbasis mobile. Berarti memprediksi kejadian yang akan terjadi dengan data historis dan memproyeksikannya ke masa depan menggunakan perhitungan matematis yang tertuang dalam aplikasi mobile, sehingga dapat di akses dimanapun dan kapanpun melalui perangkat smartphone. Perhitungan matematis yang dimaksud dalam pembahasan disini adalah penggunaan metode Weighted Moving Average. Metode ini merupakan bagian dari metode Times Series yang mengandalkan data historis atau data-data sebelumnya dan bobot yang berbeda-beda untuk memperoleh peramalan dimasa mendatang [5].

Adapun tujuan penelitian ini adalah untuk membuat aplikasi android yang mampu melakukan peramalan dengan memanfaatkan metode weighted moving average. dimana hasil penelitiannya berupa rancangan aplikasi yang siap digunakan untuk membuat aplikasi forecasting dengan bahasa pemrograman [6]. Hasil rancangan penelitian tersebut akan diimplementasikan menjadi sebuah aplikasi android dengan bahasa 
pemrograman java yang diadopsi oleh android studio selaku tools pengembangan aplikasi android yang resmi dari google[3]. Aplikasi forecasting berbasis android yang dibuat menggunakan data produksi karet sebagai sample datanya.

\section{METODE}

Urutan dalam melakukan penelitian dituangkan dalam metodologi penelitian. Tujuannya adalah agar penelitian lebih terkonsep dan terarah sesuai tujuan yang ingin dicapai, sehingga mengahasilkan sistem yang telah teruji dan dapat memecahkan permasalahan yang diteliti. Dalam penelitian ini metodologinya digambarkan kedalam bentuk sebuah kerangka kerja penelitian dimulai dari mengidentifikasi masalah, mengumpulkan data, perancangan sistem, implementasi dan hasil.

Tahapan proses kerja penelitian dimulai dari identifikasi masalah hingga tahap implementasi dan hasil. Secara umum digambarkan dalam gambar 1 .

Karena penelitian ini merupakan penelitian lanjutan dari penelitian sebelumnya, tahap identifikasi masalah, pengumpulan data, hingga tahap perancangan sistem akan diambil dari penelitian terdahulu. Hasil rancangan penelitian terdahulu akan diimplementasikan menjadi sebuah aplikasi android.

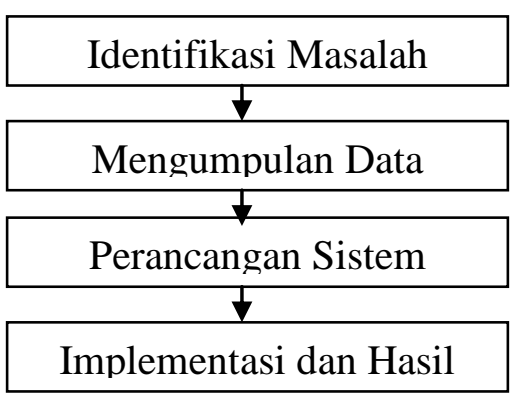

Gambar 1. Kerangka Kerja Penelitian

\section{HASIL DAN PEMBAHASAN}

Hasil dari penelitian ini adalah sebuah aplikasi mobile berekstensi .apk yang dapat dipasang pada smartphone android. Dimana aplikasi ini sudah menerapkan metode weighted moving average dalam peramalannya dan juga menampilkan persentasi errornya, sehingga siap untuk dilakukan pengujian. Data yang digunakan masih dari penelitian terdahulu, yaitu data produksi karet dari perusahaan Bakrie Sumatera Plantations.

Pembahasan dalam penelitian ini menjabarkan pengujian dan pengoperasian aplikasi peramalan. Dimulai dari tampilan awal aplikasi saat pertama kali dibuka.

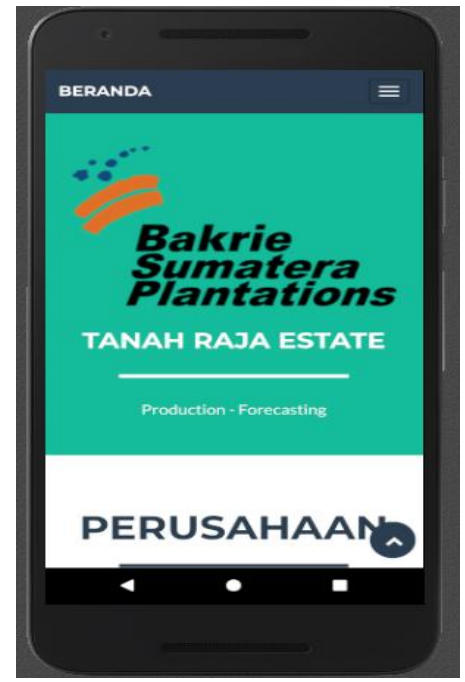

Gambar 2. Homepage Awal

Dari halaman awal terdapat menu dipojok kanan atas untuk mengakses halaman lainnya. Salah satunya halaman login, seperti terlihat pada gambar 3 . 
DOI: https://doi.org/10.33330/jurteksi.v5i2.355

Available online at http://jurnal.stmikroyal.ac.id/index.php/jurteksi

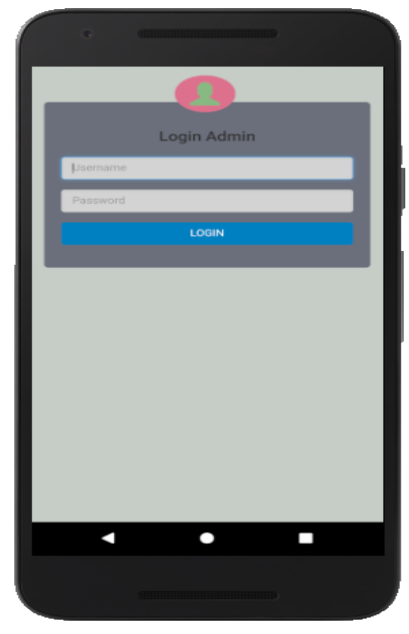

\section{Gambar 3. Halaman Login}

Setelah proses login berhasil, akan masuk ke halaman administrator. Lihat gambar 4.

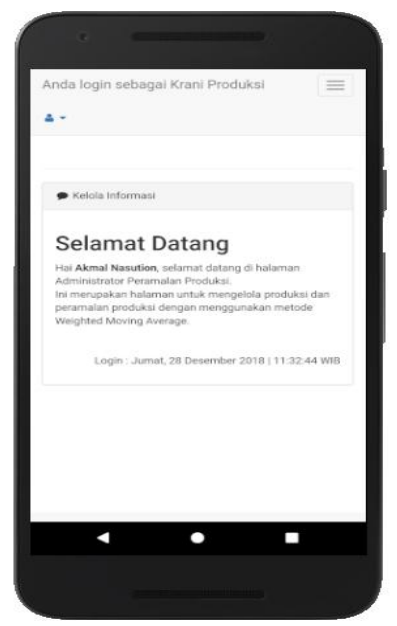

\section{Gambar 4. Halaman Administrator}

Dihalaman administrator peramalan atau forecasting dapat dilakukan dengan mengakses menu pada pojok kanan atas smartphone. Selengkapnya tentang proses peramalan dapat dilihat pada gambar 5 dan gambar 6.

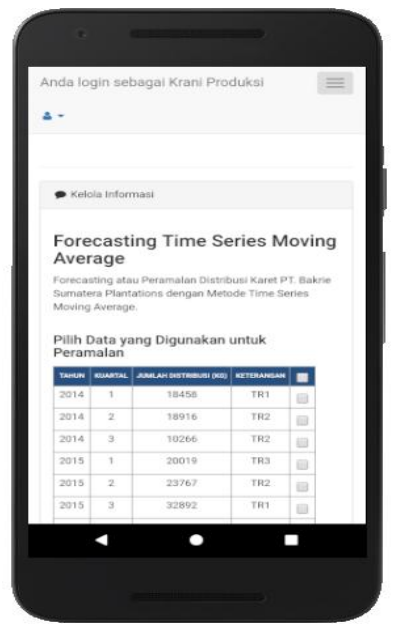

\section{Gambar 5. Mulai Forecasting}

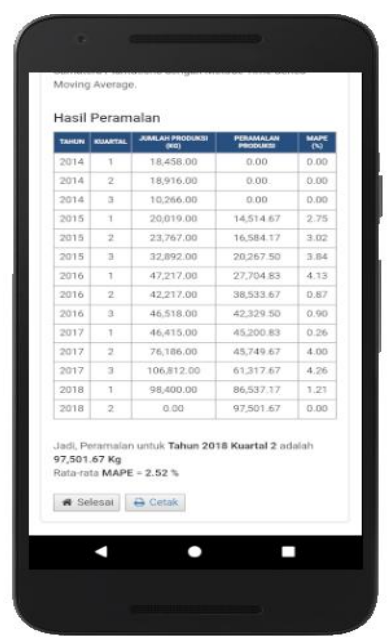

\section{Gambar 6. Hasil Forecasting}

Hasil proses forecasting menggunakan metode weighted moving average menampilkan prediksi dimasa depan dengan persentasi error yang dihitung menggunakan MAPE.

Untuk hasil pengujian aplikasi menggunakan BlackBox testing dapat dilihat pada tabel 1 dan tabel 2 .

Tabel 1 Pengujian Hasil Login

\begin{tabular}{l|l|l}
\hline \multicolumn{3}{c}{ Kasus dan Hasil Uji Login } \\
\hline Masukan & Pengamatan & Kesimpulan \\
\hline $\begin{array}{l}\text { Username } \\
\&\end{array}$ & $\begin{array}{l}\text { Masuk kedalam } \\
\text { Password }\end{array}$ & [is] Diterima \\
form login & {$[$ ] Ditolak } \\
\hline Tombol & $\begin{array}{l}\text { Keluar dari sistem } \\
\text { Logout } \\
\text { dan kembali ke } \\
\text { halaman beranda. }\end{array}$ & $\begin{array}{l}{[\sqrt{ }] \text { ] Diterima }} \\
{[\text { ] Ditolak }}\end{array}$ \\
\hline
\end{tabular}


DOI: https://doi.org/10.33330/jurteksi.v5i2.355

Available online at http://jurnal.stmikroyal.ac.id/index.php/jurteksi

Tabel 2 Pengujian Proses Forecasting Kasus dan Hasil Forecasting

\begin{tabular}{|c|c|c|}
\hline Masukan & Pengamatan & Kesimpulan \\
\hline $\begin{array}{l}\text { Pilih data } \\
\text { untuk } \\
\text { peramalan }\end{array}$ & $\begin{array}{l}\text { Sistem } \\
\text { menyimpan data } \\
\text { yang di pilih ke } \\
\text { database }\end{array}$ & $\begin{array}{l}{[\sqrt{ }] \text { Diterima }} \\
{[\quad] \text { Ditolak }}\end{array}$ \\
\hline Bobot & $\begin{array}{l}\text { Sistem } \\
\text { menyimpan } \\
\text { bobot kedalam } \\
\text { database. }\end{array}$ & $\begin{array}{l}{[\sqrt{ }] \text { Diterima }} \\
{[\text { ] Ditolak }}\end{array}$ \\
\hline $\begin{array}{l}\text { Tombol } \\
\text { Proses }\end{array}$ & $\begin{array}{l}\text { Sistem } \\
\text { menghitung } \\
\text { peramalan sesuai } \\
\text { dengan data dan } \\
\text { bobot yang } \\
\text { disimpan } \\
\text { sebelumnya. }\end{array}$ & $\begin{array}{l}{[\sqrt{ }] \text { Diterima }} \\
{[\text { ] Ditolak }}\end{array}$ \\
\hline
\end{tabular}

Dari hasil pengujian disimpulkan bahwa semua proses aplikasi berjalan dengan baik.

Selanjutnya dikumpulkan data statistik dari pengoperasian aplikasi mobile forecasting ini. Pengoperasian aplikasi menggunakan smartphone dengan spesifikasi sistem operasi Android 8 Oreo, Memori 4/64 GB, Processor Octa-core $2.0 \mathrm{GHz}$, koneksi Internet 4G. File aplikasi dalam ekstensi .apk mempunyai ukuran $1.2 \mathrm{mb}$. Data proses forecasting yang dikumpulkan dirangkum dalam tabel 3.

Tabel 3 Statistik Proses Forecasting

\begin{tabular}{clc}
\hline No & Proses & Waktu \\
\hline 1 & Instalasi file apk di smartphone & $3 \mathrm{~s}$ \\
\hline 2 & Menampilkan halaman login & $0 \mathrm{~s}$ \\
\hline 3 & Proses login & $1 \mathrm{~s}$ \\
\hline 4 & $\begin{array}{l}\text { Tampilkan halaman forecasting } \\
\text { + data yang tersedia }\end{array}$ & $1 \mathrm{~s}$ \\
\hline 5 & $\begin{array}{l}\text { Simpan data terpilih ke } \\
\text { database }\end{array}$ & $2 \mathrm{~s}$ \\
\hline 6 & $\begin{array}{l}\text { Input dan simpan bobot ke } \\
\text { database }\end{array}$ & $1 \mathrm{~s}$ \\
\hline 7 & $\begin{array}{l}\text { Proses perhitungan peramalan } \\
\text { dan error dari data terpilih dan } \\
\text { bobot }\end{array}$ & $2 \mathrm{~s}$ \\
\hline
\end{tabular}

\section{SIMPULAN}

Berdasarkan hasil dan pembahasan yang diperoleh dapat diambil kesimpulan sebagai berikut:

1. Aplikasi mobile forecasting dengan metode weighted moving average dapat berjalan dengan baik.

2. Hasil peramalan atau forecasting dapat ditampilkan dengan waktu proses kurang lebih 2 detik.

3. Total waktu yang dibutuhkan dari pemasangan aplikasi hingga proses forecasting pada smartphone adalah 10 detik.

\section{DAFTAR PUSTAKA}

[1] Siddik, M., \& Nasution, A. (2018, September). Teknologi Push Notifikasi Berbasis Android Untuk Informasi Perkuliahan (Studi Kasus: STMIK Royal Kisaran). In Seminar Nasional Royal (SENAR) (Vol. 1, No. 1, pp. 41-44).

[2] Siraj, S. (2004). Pembelajaran Mobile dalam Kurikulum Masa Depan [Mobile learning in future curriculum]. Masalah pendidikan, 27, 128-142.

[3] Stevenson, William J. \& Sum Chee Chuong. 2013. Manajemen Operasi Perspektif 110 Asia, Edisi 11, Alih Bahasa : Diana Angelica, David Wijaya dan Hirson Kurnia, (2014), Salemba Empat, Jakarta.

[4] Heizer, Jay and Barry Rander. 2014. Manajemen Operasi, Manajemen Keberlangsungan dan Rantai Pasokan, Edisi 11, Alih Bahasa : Hirson Kurnia, Ratna Saraswati dan David Wijaya, (2015), Salemba Empat, Jakarta.

[5] Gofur, A. A. (2015). Sistem Peramalan Untuk Pengadaan 
DOI: https://doi.org/10.33330/jurteksi.v5i2.355

Available online at http://jurnal.stmikroyal.ac.id/index.php/jurteksi

Material Unit Injection di PT XYZ. Komputa: Jurnal Ilmiah Komputer dan Informatika, 2(2).

[6] Nasution, A. (2018, September). Forecasting Produksi Karet Menggunakan Metode Weighted
Moving Average. In Seminar Nasional Royal (SENAR) (Vol. 1, No. 1, pp. 133-138). 